\title{
The importance of the shopping experience in times of recession: an analysis from the perspective of the hedonic and utilitarian shopping values
}

DOI:

10.7200/esicm.148.0452.3e

Link to publication record in Manchester Research Explorer

Citation for published version (APA):

Blazquez Cano, M., \& Puelles Gallo, M. (2014). The importance of the shopping experience in times of recession: an analysis from the perspective of the hedonic and utilitarian shopping values. ESIC Market Economics and Business Journal , 45(2), 273-298. https://doi.org/10.7200/esicm.148.0452.3e

Published in:

ESIC Market Economics and Business Journal

\section{Citing this paper}

Please note that where the full-text provided on Manchester Research Explorer is the Author Accepted Manuscript or Proof version this may differ from the final Published version. If citing, it is advised that you check and use the publisher's definitive version.

\section{General rights}

Copyright and moral rights for the publications made accessible in the Research Explorer are retained by the authors and/or other copyright owners and it is a condition of accessing publications that users recognise and abide by the legal requirements associated with these rights.

\section{Takedown policy}

If you believe that this document breaches copyright please refer to the University of Manchester's Takedown Procedures [http://man.ac.uk/04Y6Bo] or contact uml.scholarlycommunications@manchester.ac.uk providing relevant details, so we can investigate your claim.

\section{OPEN ACCESS}




\title{
The importance of the shopping experience in times of recession: an analysis from the perspective of the hedonic and utilitarian shopping values
}

\author{
Marta Blázquez Cano \\ University of Manchester \\ María Puelles Gallo* \\ Universidad Complutense
}

\begin{abstract}
The textile industry has been one of the most resilient in the current economic recession with positive overall results in the sector although there was a contraction of the online sales last year in Spain. Precisely e-commerce is expected to be an important source of growth in the sector in the upcoming years so it seems necessary to determine the influence of the recession on consumers' shopping behaviour.

To address this objective a quantitative approach has been taken through the application of a questionnaire to 1522 people in Spain to determine first, how consumers' shopping experiences relate to their income level and secondly, what motivates consumers to use different channels and their intentions to use them based on their working situation. The results establish the need of creating a superior shopping experience in bricks-and-mortar stores and online channel and to promote the use of e-commerce by fashion retailers.

The theoretical framework of hedonic and utilitarian shopping values is applied to measure consumers' shopping experiences and shopping motivations in a multichannel retail environment, in the textile sector, in Spain.
\end{abstract}

Keywords: hedonic value, utilitarian value, shopping motivations, bricks-and-mortar stores, e-commerce.

JEL code: M310.

*Corresponding author. Email: mpuelles@ccee.ucm.es

ISSN 0212-1867 / e-ISSN 1989-3558

(C) ESIC Editorial, ESIC Business \& Marketing School

DOI: $10.7200 /$ esicm.148.0452.3i

http://www.esic.edu/esicmarket 


\section{Introduction}

The term recession has been defined as a state in which the demand for a product is less than its former level (Kotler, 1973). According to recent studies, the global economic recession has deeply affected consumers' shopping habits worldwide (Passport, 2012). In the case of Spain an unprecedented recession, considered unique with regards to the time of recovery, is eroding the economic stability and household confidence which has generated a greater risk perception and, as a consequence, has led to a contraction of consumption and has situated Spain among the least optimistic countries in the world (Nielsen, 2012, Millward Brown, 2012).

The described background is common to all economic activity but the specific effects of the crisis on consumption are different depending on the specific activity sector. In particular, the clothing sector seems to be one of the most resilient in the current recession (Mintel, 2010). Recent data published by the Barómetro de Empresas de Moda en España (2012) indicate that the majority of Spanish fashion companies improved their turnover in 2011 and forecast positive results for the next year. The same report notes that fashion ecommerce share of market is increasing and it is expected to be one of the most important ways of growth in the fashion industry. However, according to data published by the Organización Nacional de las Telecomunicaciones y la Sociedad de la Información (ONTSI onwards, 2012) the fashion B2C market suffered an important contraction last year in Spain, in a context of growth and expansion of the online channel in other sectors. Precisely because of the contradiction that seems to arise with respect to that subject in view of the reports consulted, this research aims to determine how the economic situation has affected the consumer' relationship to fashion consumption and specifically to analyse how it influences perceptions, motivations and use of different retail channels by consumers.

Academic research related to strategic responses to economic downturn is limited and little is known about what the appropriate actions and decisions in times of crisis are (Dawson and Larke, 2004, Srinivasan et al., 2005, Sands and Ferraro, 2010). However, different authors agree that one of the main strategies applied by marketing managers to stimulate the consumer demand is the increase of marketing segmentation efforts. This strategy requires to know who the consumers are and how they behave during a crisis (Shama, 1993, Dawson and Larke, 2004). Because of that the relationship between consumers and the textile sector in times of recession will be reviewed in the next epigraph.

\section{The consumer, the recession and the textile sector}

Spanish consumers face a high rate of unemployment (INE, 2012), which has led to a reduction in the income level of an important part of the Spanish population. In addition to this real reduction of income, active workers have a negative perception 
about their working stability and the future of the economy in the country. Thus, workers feel that their income and their strength in the labour market are weakening and therefore, their consumption levels are falling (Millward Brown, 2012).

The scarcity of resources creates changes in consumers' practices of consumption (Lehtonen, 1999) and has also contributed to strengthen a consumption trend, emerged and consolidated with the recession, which is expected to continue when the economy improves: the consumers' search for value (Euromonitor International, 2011, Westbrook, 2012). The consumer is becoming more aware about prices and is more cautious and committed in his shopping activity (Grewal et al., 2009). However, this behaviour is not new. Stones' (1954) shoppers typology included the 'economic shopper', which is the segment most frequently identified in the literature. The 'price-bargain conscious shopper' (Stephenson and Willet, 1969) has evolved toward the 'economic-convenience shopper' (Bellenger and Kargaonkar, 1980) and the 'value for money consumer' (Shim and Mahoney, 1992). Value refers not just to price but to all factors that make the shopping experience as a whole (Zeithaml, 1988). This way quality is set as an important shopping aspect for fashion because a more expensive garment can provide greater value than a cheaper one (Mintel, 2010). It can be said that the recession is giving rise to a 'smart shopper' who has many tools to find the best value for money, for example comparing prices or finding the best deals on the Internet (Mintel, 2010, PWC, 2011). Due to this active seek for value, one of the main shopping motivations for consumers in times of recession is the purchase of items at reduced prices, either in sales or special promotions (Passport, 2012).

This demand of lower prices has led to the creation of new ways of collaboration between brands and channels, allowing retailers to make their products accessible to a broader segment of the population without damaging the brand image (Euromonitor International, 2009). These collaborations include ways to promote online channel as flash sales of prestigious brands across online fashion platforms (Barómetro de Empresas de Moda, 2012). But this demand for lower prices has also boosted the development of discount concepts in physical stores, popularly known as outlets (Passport, 2012). Mintel (2011) forecasts a growth of discount fashion stores in the short term in Spain while specifies that the trend could be reversed once the economy recovers due to the preference of the Spanish population to buy clothes in traditional stores.

Spaniards are highly involved with fashion (Mintel, 2011) and even though they are changing their consumption patterns due to the recession, they still continue maintaining a strong relationship with the textile sector (Millward Brown, 2012). Once basic needs have been covered, buying clothes is the second main expenditure for Spanish consumers and they plan to come back to their consumption patterns once their economic situation improves (Nielsen, 2012).

Other remarkable aspect of consumer's relationship with the textile sector is the use of fashion shopping as a reward or to change a negative mood, especially at current times (Mintel, 2010). On that issue Nicholson's et al. (2002) state that when 
the consumer looks for hedonic items, defined by the authors as 'prizes', they prefer the physical store because the physical environment reinforces the mood through social interaction opportunities, product evaluation and sensory stimulation. Visiting stores can be considered a way of scapism, a break from everyday life as shopping is seen as way in which consumers treat themselves (Bäckström and Johansson, 2006). However, recent research shows that buying clothes over the Internet is also perceived as an enjoyable activity that provides hedonic value (Clifford, 2012).

Whether the consumer chooses one channel or another in recessionary times is related with the search for aesthetics as well. Lehtonen (1999) demonstrated that the lack of resources makes consumers see the shopping activity in a new light and that they are able to find aesthetic meaning in consumption even when their resources are limited.

Generally it can be said that the recession is having a bigger impact on physical stores than on the Internet. Dawson and Larke (2004) found that retailers who chose to open more stores as a strategy to generate more sales in times of economic downturn had high levels of debt and low productivity and the strategy proved to be a mistake. However, retailers who invested on online channel were successful. In fact the crisis is boosting the consumer migration to the online channel and it is expected that this trend will continue when the economic situation improves (Euromonitor International, 2011).

Recent data shows that e-commerce is growing worldwide and even in Spain at a lower pace (ONTSI, 2012). E-commerce is a retail channel that helps consumers to save money in times of recession through the purchase of products and services at discount prices and through the access to downloadable coupons and daily deals (Passport, 2012). Internet makes easier to establish the correlation between price and value for a specific product as well (PWC, 2011). In fact, the European Commission estimated at 204 billion euros the overall gain for consumers in the hypothetical situation that $15 \%$ of total sales would be made through the Internet (European Commission, 2012). However, there is little agreement about the relationship between consumers' working situation and the development of the Internet as a retail channel. On the one side it has been pointed out that the increasing level of youth unemployment could lead to a lower development of e-commerce in some categories (Mintel, 2010b) and that, in fact, unemployed people are in risk of digital exclusion in Spain (Fundación Orange, 2012). On the other side it has been defended that unemployed people have more time to use the Internet and find the best deals, which leads to a higher development of the channel. In addition, working people have less leisure time and they could use Internet to save time in their in-store shopping (Passport, 2012). This lack of agreement indicates a need to understand this relationship in detail. 


\section{Literature review}

The shopping experience: hedonic and utilitarian shopping values

The concept of value has been defined in multiple ways in the literature. Zeithalm (1988) carries out an extensive review of the concept and comes to the concept of value as 'all factors, both qualitative and quantitative, subjective and objective, that make up the complete shopping experience' (Zeithaml, 1988, pp. 13). So value is not limited to the acquisition of the product but it is derived from the consumption experience generated from that acquisition (Holbrook, 1996).

Shopping value can be both, hedonic and utilitarian (Babin et al. 1994). The hedonic shopping value reflects the value received from the multisensory, fantasy and emotive aspects of the shopping experience (Hirschman and Holbrook, 1982). It is subjective and individualistic and it is related with nouns such as fun, pleasure or enjoyment (Irani and Heidorzaden, 2011). On the other hand, utilitarian shopping value is a rational, task-oriented (Arnold and Reynolds, 2003), cognitive and non-emotional outcome of shopping (Hirschman and Holbrook, 1982). Hedonic and utilitarian dimensions are important because they are present in all consumption processes, involving all shopping experiences and consumer behaviour (Batra and Ahtola, 1990, Jones et al. 2006).

Although most shopping experiences produce both values, the outcome may be different based on factors such as the product purchased or the retail channel used. With regard to the product, clothing is classified as a highly hedonic product category due to its symbolic, experiential and pleasing properties (Crowley et al, 1992; Levy, 1959) and the creation of hedonic environments is especially important for products with strong hedonic attributes (Childers et at., 2001). But to measure and to understand the complete shopping experience, the utilitarian side of shopping must be considered as well as the hedonic side (Holbrook and Hirschman, 1982).

Therefore it can be determined that both values are needed to explain the buying process (Arnold and Reynolds, 2003; Irani and Heidorzaden, 2011) and that the shopping value is a key element to understand consumer behaviour and to predict consumers' shopping intentions (Irani and Heidorzaden, 2011) making it the appropriate theoretical framework to develop this research.

Next it will be explained how consumers' income level relates to the hedonic and utilitarian value perceived in their shopping experiences. This aspect will allow us to establish the foundations that relate situations of economic recession with possible changes in value' perceptions.

\section{The importance of consumers' income level}

Under the premise that social class differences go beyond and condition more than income differences, Martineau (1958) establishes psychological differences 
between individuals from different social classes. His research states that the goals and mental processes of individuals belonging to different classes are different. Coleman (1983) refers to this research to indicate that social class is a complex and methodologically challenging segmentation variable while income level is equally significant but easier to apply.

Among the first studies that apply income level as a segmentation variable, it could be highlighted that by Bellenger et al. (1976), which showed that income is a key variable to explain shopping behaviours. Goldman (1976) agrees on that point confirming that there are significant differences in shopping behaviour, shopping goals and objectives between low and high-income consumers.

Afterwards, academic research started to relate the income level with the hedonic and utilitarian shopping values. Bellenger et al. (1977) provide a typology of consumers based on their shopping motivations, characterising the 'recreational shopper' or hedonic, low-income shopper and the 'economic shopper' or utilitarian, high-income shopper. Consistent results have been found by Dawson et al. (1990), who concluded that the experiential shopping motivation was inversely related to the consumer' income level. Meanwhile, Sit et al. (2003) classified consumers considering high, middle and low income levels. They got four groups: two groups composed of hedonic consumers with low and middle income level and other two groups composed of utilitarian consumers with high and middle income level. These results suggest that middle-income consumers are not clearly positioned in any group but differences are kept between high and low income consumers. In order to prove that these findings were also applicable to the shopping process in malls, Allard et al. (2009) analysed how hedonic and utilitarian shopping perceptions were related to consumers' income level confirming the theory that high-income consumers are more sensitive to the utilitarian dimension of the experience, while low-income consumers are more sensitive to hedonic elements.

In any case, whether in the physical store or in the Internet, consumers expect a superior shopping experience consistently with their search for hedonic and utilitarian values. Considering that a satisfying shopping experience generates higher retailer loyalty with clear long-term benefits, the creation of a superior experience means a bigger challenge for retailers during recession (Manning and Dorsey, 2008) and therefore it seems necessary to know more about Spaniards' shopping behaviour in these times.

\section{Motivations to use retail channels}

It is always important to know what reasons motivate consumers to use different retail channels but in the current recessionary environment this is even critical.

Considering the high rate of unemployment in Spain (INE, Dec. 2012) it is mandatory to analyse the behaviour of this increasing group of consumers compared with the behaviour of active workers. From the data presented by Millward Brown 
(2012) it can be concluded that there are no extreme differences between unemployed and workers about their attitudes toward saving and cost containment. In fact, the climate of general pessimism installed in our society can make the differences between them not as significant. The literature does not make a clear difference about how workers and unemployed people use or intend to use different retail channels. However fashion retailers must understand what motivates both groups to buy in physical stores and online, so that they can segment their offer and communications to them as far as possible. In any case, the importance of hedonic shopping motivations for Spanish consumers has been proved by Gavilán Bouzas et al. (2010),

Few human behaviours are as purposeful as shopping (Puccinelli et al. 2009). Tauber (1972) was the first author in exploring the shopping motivations behind consumers' shopping behaviour with the premise that shoppers are motivated not just for the functional characteristics of the products but also for the satisfaction obtained during the shopping process. With this premise Westbrook and Black (1985) developed different dimensions of shopping motivations, all containing hedonic and utilitarian elements, but some being more hedonic and others more utilitarian in nature. Building on Tauber's research, Hirschman and Holbrook (1982) included new motivations as pleasure, emotion and enjoyment as opposed to the conventional utilitarian motives. These authors, based on Maslow and Freud theories, point out that sometimes emotional desires dominate over functional motivations in the choice of products. In order to measure these motivations Arnolds and Reynolds (2003) developed a scale of hedonic motivations applied to the physical channel that will be used in this research. They are 'Adventure Shopping' that refers to the exploratory shopping in searching for stimulation; 'Social Shopping' as the enjoyment of shopping with family or friends with the objective of socializing and being in touch with others while shopping. 'Gratification Shopping' refers to going shopping to reduce stress or to change a negative mood while 'Idea Shopping' has the objective of being aware of the latest trends or see the new products in the store. Last, 'Value Shopping' refers to the bargain hunting or sales shopping. These shopping motivations are in the base of the To et al. (2007) research, applying them to the online context and including utilitarian motivations as well. Three of these utilitarian motivations will be applied in this research as well: 'Convenience', 'Selection' and 'Cost-Saving'.

\section{Methodology}

\section{Objectives, structure and hypothesis development}

Based on the previous studies, this research will seek to determine their applicability in the case of a particular sector, the textile industry, and in the case of two channels, bricks-and-mortar stores and online channel in the current context of economic recession. 
As noted in the introduction, the main aim of this research is to determine the influence of the recession on consumers' shopping behaviour in the textile sector. This main aim is divided into two objectives:

- First, to establish the relationship between consumers' income level and the value perceived in their fashion shopping experiences.

- Second, to determine the influence of consumers' working situation on their motivations and intentions to use different channels in the textile sector.

Next, focused on the first objective and on the previous literature review the following hypotheses are proposed. These hypotheses are based on the next assumption derived from the literature review: there are significant differences in the hedonic and utilitarian shopping value perceived by consumers in their shopping experiences based on their income level. This way:

H1: Low-income consumers are more sensitive to the hedonic dimension of the shopping experience in bricks-and-mortar stores than high-income consumers

H2: High-income consumers are more sensitive to the utilitarian dimension of the shopping experience in bricks-and-mortar stores than low-income consumers

H3: Low-income consumers are more sensitive to the hedonic dimension of the shopping experience in the Internet than high-income consumers

H4: High-income consumers are more sensitive to the utilitarian dimension of the shopping experience in the Internet than low-income consumers

As indicated in the literature review it has not been found relevant literature that relates the working situation with the different behavioural and shopping outcomes considered in this research. In consequence, the second part of the research will be exploratory in nature. Given this situation and focusing on the textile sector, it will seek to determine:

- Search and purchase intentions of active workers versus unemployed people in physical stores and in the Internet.

- Their motivations to use each of these channels.

\section{The questionnaire}

A quantitative approach has been taken in order to address the objectives of this research, applying a questionnaire (Allard et al., 2003, Jones et al., 2006, Irani and Heidarzadeh, 2011). Two different retail channels have been considered - bricksand-mortar stores and the Internet - and respondents were asked to evaluate and compare their last shopping experiences in each of them.

The questionnaire is divided in 3 parts, with different objectives each. 
1. The first part of the questionnaire has an exploratory objective and focuses on the general use of the Internet by individuals. The questions are based on information provided by ONTSI, GMI and Eurostat and include aspects such as frequency of use of the Internet, more frequent activities on the Internet, what people search for, what people buy online and barriers to online shopping.

2. The second part of the questionnaire aims to measure consumers' perceptions and motivations about their last shopping experiences in physical stores and on the Internet, applying the proposed theoretical framework. Consumers were asked to think about the last time they bought fashion in both channels, understanding by that the process of searching and/or buying for fashion items.

In-store and online shopping were considered as two independent experiences so that consumers could focus on them more easily (Nicholson et al. 2002, Verhoef et al. 2009). In both cases, consumers were asked to think about the last time they browsed and/or bought in both channels, being each channel the most important one used in that concrete shopping process.

In order to make respondents remember more clearly their last shopping processes in stores and online, a question about what they bought was included, incorporating 'nothing' as a choice, because a shopping process can provide hedonic value itself, even when you do not buy anything (To et al., 2007).

To measure consumers' last shopping experiences we have applied the Personal Shopping Value scale developed by Babin et al. (1994) and widely used by academics to study consumers' shopping behaviours. The scale consists of 15 items, 11 referred to hedonic shopping value and 4 referred to utilitarian shopping value. Participants had to indicate their degree of agreement with the different items using a 5-point Likert scale ranging from absolutely disagree (1) to absolutely agree (5).

Consumers' motivations to search and/or buy fashion through the Internet have been measured as well. For hedonic motivations, individual items have been taken from Arnolds and Reynolds (2003), who developed and validated their own scale. The motivations included have been 'adventure shopping', 'gratification shopping', 'idea shopping', 'value shopping' and 'social shopping' as described before. In relation to utilitarian motivations 'convenience', 'cost-saving' and 'selection' have been considered. The items have been taken from To et al. (2007). These authors adapted 'convenience' and 'selection' from Eastlick and Feinberg (1999), who developed both motivations for mail catalogue shopping. 'Cost-saving' was developed by Chandon et al (2000) in the context of sales promotions. The three motivations were modified to adapt to the special conditions of Internet shopping and the complete survey instrument was subsequently validated by To et al (2007).

Then based on these last shopping experiences respondents were asked to show their search and purchase intentions in both channels, idem with a 5-point Likert scale ranging from absolutely disagree (1) to absolutely agree (5). The items to measure both intentions have been taken from To et al. (2007).

3. The last part of the questionnaire is devoted to demographics, including gender, age, work activity and income level as they are relevant to the research topic and will be considered in different parts of the analysis. 
The procedure of developing the questionnaire was followed by a consultation with experts from the University of Oxford and Complutense University of Madrid in order to improve its effectiveness, which resulted in a number of changes. Then a pilot test was conducted to confirm that all items were properly understood. As a result, some elements were modified -the most relevant was the elimination of one of the items measuring perceived utilitarian value for generating confusion- and the questionnaire was launched.

The questionnaire was applied between March and August 2012, having obtained 1522 complete answers in Spain.

Next, the target for this research is defined and the sampling procedure applied is described.

\section{Sampling procedure and target of the research}

The definition of the characteristics of the sample depends on the objectives of the research. In this particular case, it has been pursued to conduct research that reflects different age groups and both genders to overcome the limitation noted by different authors who say that research about fashion shopping is mostly focused on students and females (Marciniak and Bruce, 2007). As a consequence, a wider target was defined for this research: men and women, aged 16 - 60 years old and with shopping experience for fashion and accessories in physical stores and through the Internet (meaning by shopping experience the process of search and/or purchase in both channels).

The questionnaire was conducted online using a snowball sampling procedure. This sampling method has been widely used in social research having demonstrated to be an efficient and effective method to provide in-depth and relatively quick results (Biernacki and Waldorf, 1981). It has been defined as 'a random sample of individuals drawn from a given finite population' (Goodman, 1961, p.148) in which each individual in the sample is asked to send the questionnaire to different individuals in the population. The data obtained using this procedure can be used to make statistical inferences about different aspects of the relationships present in the population (Goodman, 1961).

Snowball sampling procedure belongs to the group of ascendant methodologies characterised by its straightforwardness to reach participants who would otherwise be difficult to get (Van Meter, 1990). As an example, the older population in our research would have been more difficult to identify. But this sampling method also presents some limitations such as the validation of the sample (Van Meter, 1990, Kaplan et al, 1987) or the fact that the research could be restricted to certain social networks if a phenomenon of limited scope is being studied (Van Meter, 1990).

Certain authors recommend working with large samples that are demographically representative (Pollok and Schlitz, 1988) to minimise the limitation of sample 
validation presented by the snowball sampling method (Van Meter, 1990; Kaplan et al, 1987). This research meets these requirements as sample size is $n=1522$ and sample is demographically representative of the population studied based on data about the profile of the Internet shopper in Spain (ONTSI, 2012). Besides, the issue studied is a nationwide phenomenon not limited to certain networks. Last, in order to achieve the sample based on the defined profile, emails of people from different cultural, economic and professional backgrounds who fitted into the requirements were selected in order to attain a large number of non-related people to distribute the questionnaire, following Van Meter's (1990) recommendation to avoid that they share some characteristics between them that are not shared by the rest of the population.

\section{Sample Demographics}

Table 1 shows the specific demographic characteristics of the sample obtained. The gender distribution is balanced with 50.3 per cent of women and 49.7 per cent of men. The 75.6 per cent of respondents are aged between 16 and 44 years old and the majority $-62,8$ per cent- are workers while 6.7 per cent are unemployed and the rest 25.9 per cent are students. There is representation of low, middle and high-income levels.

The sample demographics confirm the fact that the Internet is becoming increasingly prevalent among the general population (Watchravesringkan and Shim, 2003). Furthermore this demographic profile fits into the profile of the Spanish Internet shopper offered by ONTSI (2012), which makes the sample relevant for our object of study.

Table 1: Sample Demographics

\begin{tabular}{lc}
\hline Gender & \\
Male & $49,7 \%$ \\
Female & $50,3 \%$ \\
\hline Age & \\
From 16 to 24 years & $21,2 \%$ \\
From 25 to 34 years & $30,8 \%$ \\
From 35 to 44 years & $23,6 \%$ \\
From 45 to 54 years & $13,9 \%$ \\
54 years or more & $10,5 \%$ \\
\hline Working Activity & \\
Full-time worker & $49,6 \%$ \\
Part-time worker & $13,2 \%$ \\
Housemaker & $4,7 \%$ \\
Student & $25,9 \%$ \\
Unemployed & $6,7 \%$ \\
\hline
\end{tabular}

\begin{tabular}{ll}
\hline Income Level (monthly) & \\
Less than $600 €$ & $30,9 \%$ \\
From 500 to $999 €$ & $14,6 \%$ \\
From 1000 to $1999 €$ & $30,6 \%$ \\
From 2000 to $2999 €$ & $14,0 \%$ \\
From 3000 to $3999 €$ & $4,6 \%$ \\
From 4000 to $4999 €$ & $2,3 \%$ \\
$5000 €$ or more & $3,1 \%$ \\
\hline
\end{tabular}

Source: compiled by authors. 


\section{Results}

\section{Exploratory factor analysis}

Construct validity of the scales applied was confirmed with the use of Exploratory Factor Analysis, applying principal component method with varimax rotation to determine how observed variables were linked to their underlying factors in the multi-item scales applied for both channels (Allard et al., 2009).

With regards to the Personal Shopping Value scale, the data get the requirements for sample adequacy (Bernal et al., 2004): in bricks-and-mortar stores, $\mathrm{KMO}=$ 0.898 , and in the Internet, $\mathrm{KMO}=0.913$, being Barletts' test of sphericity significant in both cases (.000). All item loadings were greater than 0.4 , level commonly considered significant (Ford et al., 1986). Last, the total variance explained by the two factors is 54.7 per cent in the case of bricks-and-mortar stores and 58.6 per cent in the case of the Internet, which confirms the dimensional structure of the scale (Henson and Roberts, 2006).

In the scale referred to search and purchase intentions, $\mathrm{KMO}=0.769$ for bricksand-mortar stores and $\mathrm{KMO}=0.695$ for the Internet, being Barletts' test of sphericity significant as well. Al item loadings were greater than 0.7 in bricks-and-mortar stores and than 0.9 in the case of the Internet, so they are significant in the sample. The total variance explained by two factors is 90.4 per cent in both cases.

\section{Income level and consumers' shopping experience}

The first thing done has been the segmentation of the sample in 3 different groups: low, middle and high-income consumers (Allard et al, 2009). This segmentation is based on data provided by the Instituto Nacional de Estadísitica, INE onwards, relative to the average wage of Spaniards (INE, 2012). INE sets the Spanish average wage in $1701,62 €$ monthly gross and $1345,44 €$ monthly net, so it has been considered the income range in which this amount is included as middle income -from $1000 €$ to $1999 € /$ month-; income levels that are below the average wage are considered as low-income -up to $999 € /$ month-; and those above the average as high-income -between 2000 and $5000 € /$ month-. Next, the mean of the hedonic and utilitarian shopping value perceived by the respondents in their latest shopping experiences in stores and online is calculated. The results are shown in Table 2: 
Table 2. Consumers' perceived value based on their income level

\begin{tabular}{ccccc}
\hline \multicolumn{2}{c}{ Income Level } & Low Income & Middle Income & High Income \\
\hline \multirow{2}{*}{$\begin{array}{c}\text { Bricks-and-mortar } \\
\text { Stores }\end{array}$} & Hedonic Value & 3,05 & 2,95 & 2,84 \\
& Utilitarian Value & 3,26 & 3,31 & 3,45 \\
\hline \multirow{2}{*}{ Internet } & Hedonic Value & 2,65 & 2,60 & 2,58 \\
& Utilitarian Value & 3,24 & 3,20 & 3,22 \\
\hline
\end{tabular}

Source: compiled by authors.

In the case of bricks-and-mortar stores, the hedonic value is inversely related to the income level, while the utilitarian value is directly related to it. In the case of the Internet it occurs in the same way with the hedonic value but not with the utilitarian.

The literature review suggested differences between high and low income consumers and the research hypotheses have been formulated based on that so it has been tested if the differences between these groups are significant, applying ANOVA analysis (Field, 2010). The result obtained is shown in Table 3:

Table 3. ANOVA Hedonic and Utilitarian Value, Bricks-and-Mortars' and Internet based on Income Level

ANOVA

\begin{tabular}{|c|c|c|c|c|c|c|}
\hline & & SS & gl & $\begin{array}{c}\text { Roat Mean } \\
\text { Square }\end{array}$ & F & Sig. \\
\hline \multirow{3}{*}{ HedonicTiendaMean } & Inter-groups & 10.319 & 1 & 10.319 & 13.814 & .000 \\
\hline & Intra-groups & 746.250 & 999 & .747 & & \\
\hline & Total & 756.569 & 1000 & & & \\
\hline \multirow{3}{*}{ UtilitaTiendaMean } & Inter-groups & 8.190 & 1 & 8.190 & 9.595 & .002 \\
\hline & Intra-groups & 852.761 & 999 & .854 & & \\
\hline & Total & 860.951 & 1000 & & & \\
\hline \multirow{3}{*}{ HedonicIntMean } & Inter-groups & 1.273 & 1 & 1.273 & 1.843 & .175 \\
\hline & Intra-groups & 690.015 & 999 & .691 & & \\
\hline & Total & 691.288 & 1000 & & & \\
\hline \multirow{3}{*}{ UtilitIntMean } & Inter-groups & .087 & 1 & .087 & .107 & .744 \\
\hline & Intra-groups & 812.945 & 999 & .814 & & \\
\hline & Total & 813.032 & 1000 & & & \\
\hline
\end{tabular}

Source: compiled by authors. 
For conventional stores, the differences between the two groups are significant for both values, hedonic and utilitarian, so both hypotheses $\mathrm{H} 1$ and $\mathrm{H} 2$ are supported and therefore it can be confirmed the applicability of Allard et al.'s (2009) theories for Spanish consumers.

It is different, however, in the case of e-commerce. The mean differences between groups for both values are not significant so neither $\mathrm{H} 3$ nor $\mathrm{H} 4$ are supported. The convenience that the Internet represents for high-income consumers for being an utilitarian channel by nature and for low-income consumers for the opportunities it offers to save money can justify the similar perceptions of both groups with regards to the channel.

The hypotheses tested and the results obtained are shown in Table 4.

Table 4. Hypothesis testing

\begin{tabular}{clc}
\hline $\begin{array}{c}\text { Hypotheses } \\
\text { Number }\end{array}$ & \multicolumn{1}{c}{ Hypotheses } & Test Result \\
\hline $\mathrm{H} 1$ & $\begin{array}{l}\text { Low-income consumers are more sensitive to the hedonic dimension } \\
\text { of the shopping experience in bricks-and-mortar stores than high-in- } \\
\text { come consumers }\end{array}$ & Supported \\
\hline $\mathrm{H} 2$ & $\begin{array}{l}\text { High-income consumers are more sensitive to the utilitarian dimen- } \\
\text { sion of the shopping experience in bricks-and-mortar stores than } \\
\text { low-income consumers }\end{array}$ & Supported \\
\hline $\mathrm{H} 3$ & $\begin{array}{l}\text { Low-income consumers are more sensitive to the hedonic dimen- } \\
\text { sion of the shopping experience in the Internet than high-income } \\
\text { consumers }\end{array}$ & Rejected \\
\hline $\mathrm{H} 4$ & $\begin{array}{l}\text { High-income consumers are more sensitive to the utilitarian dimen- } \\
\text { sion of the shopping experience in the Internet than low-income } \\
\text { consumers }\end{array}$ & Rejected \\
\hline
\end{tabular}

Source: compiled by authors.

These results draw a first sketch of the relationships of consumers with retail channels. In order to understand more clearly this analysis, it is necessary to go in depth into consumers' intention of use of channels and into the motivations to buy in different channels in times of recession. This will be done next. 
The influence of the economic recession on consumers' search and purchase intentions and motivations to use different channels

Search and purchase intentions

With the objective of establishing how active workers and unemployed people intend to use retail channels, their search and purchase intentions in physical stores and in the Internet have been analysed (To et al. 2007). Because of that the sample has been segmented into two groups: the group of workers, consisting of 905 people, including full-time workers (715) and part-time workers (190), and the group of unemployed composed of 96 people.

Table 5 shows the results for each consumer group in each channel.

Table 5. Search and Purchase Intention means based on Working Situation

\begin{tabular}{lcccc}
\hline & \multicolumn{2}{c}{ Unemployed } & \multicolumn{2}{c}{ Workers } \\
\hline Use of Channels & Stores & Internet & Stores & Internet \\
Search Intention & 3,89 & 3,27 & 3,91 & 3,31 \\
Purchase Intention & 3,99 & 2,99 & 3,97 & 3,13 \\
\hline
\end{tabular}

Source: compiled by authors.

With the aim of determining which is the main channel used to browse and buy for clothing for each group of consumers, the means observed in Table 5 need to be tested to determine if they are statically significant. To achieve that, a statistical test for paired samples has been run comparing the search intention and purchase intention between the two channels and within each group. The result for both groups is that 'search intention' and 'purchase intention' are significantly higher in physical stores than on the Internet.

To some extent, these results are expected because even when the Internet is a relevant medium for Spanish consumers and e-commerce is growing, it is still less developed compared to other European countries, and the difference is higher when we compare it with physical stores (Seybert, 2011). These results suggest that Spanish consumers are still very close to physical channels.

\section{Motivations to use retail channels}

In order to establish what motivates both groups of consumers to buy in the channels considered, the mean of each shopping motivation for each group has been calculated for both channels. The results are exposed in Table 6: 
Table 6. Shopping Motivations based on Channel and Working Situation

\begin{tabular}{lcccc}
\hline & \multicolumn{2}{c}{ Unemployed } & \multicolumn{2}{c}{ Workers } \\
\hline Motivations & Store & Internet & Store & Internet \\
\hline Gratification & 3,01 & 2,29 & 2,83 & 2,41 \\
Adventure & 2,33 & 2,22 & 2,29 & 2,30 \\
Value & 3,3 & 2,56 & 3,14 & 2,58 \\
Idea & 2,41 & 2,48 & 2,46 & 2,52 \\
Convenience & 3,31 & 3,56 & 3,31 & 3,93 \\
Cost-Saving & 2,67 & 3,04 & 2,74 & 3,26 \\
Social & 3,42 & 3,04 & 3,29 & 3,14 \\
Selection & 3,36 & 3,42 & 3,38 & 3,7 \\
\hline
\end{tabular}

Source: compiled by authors.

The differences between means are similar for unemployed and workers for most motivations, with the exception of 'adventure shopping'. 'Adventure shopping' is a hedonic motivation whose mean is higher for workers when they buy through the Internet while for unemployed people is higher when they buy in physical stores.

Newly it is necessary to run a t-stat for paired samples to determine whether these differences in the motivations to use each channel are significant within each group. In the case of unemployed people just 'gratification' and 'value' are significantly higher in the case of physical stores. For the rest of motivations, the means differ between channels, but these differences are not significant.

In the case of working people, they coincide on 'gratification' and 'value' that are significantly higher in conventional stores. However, the motivations of 'convenience', 'cost-saving' and 'selection' are significantly higher online than in the physical store.

As a conclusion, it can be said that workers are strongly motivated to use e-commerce while unemployed people seem to be 'stuck' to physical stores. In the next section the implications of these results will be discussed and recommendations from them will be addressed.

\section{Implications and Recommendations}

Once the data have been analysed this section will focus on the theoretical contribution of this research and the potential applicability of the findings exposed, based specifically on the hedonic and utilitarian shopping value and motivations that strongly affect each group. Then possible ways of enhancing the fashion commercial activity, applicable to this time of recession, will be suggested, but thinking of the 
long-term as well. Sands and Ferraro (2010) analyse retailers' strategies in times of recession over the theory that their response is mediated by the organisation size, geographic location and retail sector (Shama, 1993). Our recommendations focus on the fashion sector and the Spanish market and some appreciations based on the size of retailers will be made too.

From a theoretical perspective this research contributes to the understanding of the consumer shopping experience in a multichannel retail environment for a specific sector, fashion retailing, in a particular recessionary context. As an experiential theoretical framework -hedonic and utilitarian shopping values and motivations- has been applied, the research contributes to extending in some way this theory to a different market context. As an example, this research has demonstrated the applicability of Allard et al (2009) theories to the Spanish market in the case of physical stores while the peculiarities of online channel make it difficult to apply them there. In addition, this article contributes to improve the knowledge of the hedonic and utilitarian determinants in consumers' shopping experiences in stores and online and the influence of these variables on key shopping outcomes as are search and purchase intentions in those channels. Specifically, from an exploratory point of view, it generates some insights that relates consumers' working situation with motivations and intentions to use different channels.

From a managerial point of view, the relationship between consumers' income lev$\mathrm{el}$ and their perceptions about their shopping experiences generates interesting results. It indicates that low-income consumers give more value to the hedonic elements of their shopping experience in conventional stores compared with high-income consumers. This may be due to the scarcity of resources that leads them to value more what they buy and with it the whole search and/or purchase process. The result is consistent with Lehtonen (1999) and Allard et al. (2009) theories, which are confirmed in a different retail sector. Low-income consumers are much more conscious and demanding and value more their shopping experiences for being more scarce and selected. Retailers must ensure, therefore, a positive and enjoyable shopping experience that generates value versus other alternatives; a shopping environment that makes fashion shopping a relaxed, fun, pleasurable and convenient activity, according to consumers' needs (Chu and Lam, 2007). In fact, a convenient experience is what high-income consumers expect from physical stores. The scarcity of time can be one of the reasons to explain why the utilitarian elements of the shopping experience are crucial for them, together with the fact that they do no need to select the shopping moments so much so they do no value these moments in the same way.

However, when these theories are applied to the online channel things do no work in the same way. Precisely, in the case of the Internet, there were differences in consumers' perceptions based on their income-level but the ANOVA results showed that these differences between groups were not significant. The explanation for this may be that the Internet is considered as a primarily utilitarian channel (To et al., 2007, Camus and Bracewell 2009) which makes it suitable for high income individuals, but on the other hand, is a channel that gives access to multiple offers and good 
deals and can help consumers to save money, so it is also suitable for individuals with lower incomes. Because of this e-commerce seems specially recommended in times of economic downturn, since the Internet appeals to consumers' desire to find 'bargains' (Passport, 2012).

It is important to notice that within the group of low-income consumers it can be found one of the most important targets for fashion retailers: young people. The called 'Reset Generation' is going to face the effects of an era of austerity and unique circumstances in terms of technology, employment, politics and environment (Initiative, 2011). Young people, especially aged 16-24, have a more 'passionate' relationship with fashion and a more carefree attitude towards recession (Mintel, 2010). Furthermore, their use of technology involves a totally different experience with the textile sector. In any case, they share with other low-income consumers their seek for a different and hedonic experience, being even more demanding in their shopping experiences in conventional stores and in the Internet.

The analysis of data shows that both workers and unemployed use the traditional store as the main channel to browse and buy for clothing, and therefore it seems necessary to promote e-commerce in these groups. In fact, e-retailing was one of the main keys of success of Japanese retailers during the 90's, a decade of slow growth in the country (Dawson and Larke, 2004). A good way of doing it would be precisely through physical channels and through all points of contact between retailers and consumers including social networks. Marketing actions such as the launch of a collection online previous to the store, exclusive discounts or exclusive products in the web store would help to drive consumers to the online channel and, as a consequence, they would discover a shopping experience that goes beyond functional elements. Thus, retailers must take care of instrumental aspects as convenience, savings, easiness of comparison and choice and other attributes that characterise the digital channel without forgetting that hedonic and social reasons, important for shopping in general, so are for shopping through the Internet (Childers, 2001). For example retailers should increase the presence of the atmospherics - music, design, sensory elements (Eroglu et al., 2003) and develop more stimulating webs, offering viral content, catwalk videos, product suggestions or fashion design programmes (Sender, 2011). Consumers are looking for an interactive and exciting online experience that replicates as much as possible the in-store shopping experience: 3D technologies, virtual models or augmented reality can also contribute to this (Siddiqui et al, 2003). On top of it, Spanish consumers are getting used to this experience through fashion blogs and foreign websites, as this is the kind of experience that develop pure-play retailers like Asos or Net a porter.

The promotion of e-commerce is also important because it offers the possibility to buy anywhere. Given that people aged 15-45 years are the main consumers of clothing and accessories in our country and are one of the most affected by the growing emigration process as well, it would be interesting to attract and retain these consumers as soon as possible, for them to continue shopping regardless of their place of residence. Otherwise, this emigration, along with the ageing of the population, can 
lead to big losses for fashion retailers in the upcoming years in Spain (Mintel, 2011).

One of the main contributions of this paper is the characterisation of this new consumer that actively seeks for value in their consumption decisions. The Oxford Retail Futures Conference is a space that aims to set new trends in retail and consumer behaviour and in the last edition (Dec. 2012) it was settled that this new consumer, with their value-oriented shopping behaviour, will modify the structure of business models and the concept of value, in the way they are now understood. What should fashion retailers do about it?

First, it has been said that value does not mean just price or low quality products, but rather the opposite. Therefore a price promotion policy can be dangerous because it erodes margins and does not create consumer loyalty (Mintel, 2010). The price and discounts war is increasing sales now but in the long term is expected to have negative effects for the whole sector (Barómetro de Empresas de Moda, 2012).

Retailers can create value following a differentiation strategy via the service offered (Sands and Ferraro, 2010). In the case of fashion retailers the design of the spaces is an important element to create value. Ballantine et al. (2010) refer to the use of attractive stimuli in the store, pointing out that interactive displays attract attention and engage customers. The introduction of new elements stimulate consumers' interest and attention and are important for inspiring consumers as well, creating more pleasurable in-store experiences (Bäckström and Johansson, 2006). Recently, stores have succeeded in communicating the values of the brand and exposing consumers to a multisensory experience (Surchi, 2010).

Another way to create value for the consumer is through the use of data mining to generate personalised offers and promotional appeal (Shama, 1993, Sands and Ferraro, 2010) as personalisation seems to be one of the main consumer trends now (Clifford, 2012). This trend is consistent with the recommendation set up by Srinivasan et al. (2005) about the need to invest in marketing activities during economic downturns to improve companies' business performance.

The offer of exclusivity to the consumer with limited collections/editions or collaborations with famous designers has become an important way of differentiation for fashion retailers. This has been the strategy adopted by retailers such as H\&M or Top Shop in recent years. Related to specific products, there should be a move towards quality and most timeless items; regardless of the specific positioning of the retailer, all of them should have these garments (Mintel, 2010).

All these recommendations work in benefit of the brand image of the company as it does the ethical commitment of the retailer. Precisely, the green and sustainable practices are another strategic response of retailers during the recession (Sands and Ferraro, 2010).

In addition, big retailers have the possibility to offer synergies between their different channels, an option that may be especially appealing for the multichannel consumer (Zhang et al, 2010). Services like 'click and collect' (buy online, pick up in the physical store) or returns in store will help to boost the online channel and will generate greater customer loyalty if the customer service works properly 
(Euromonitor International, 2011). For smaller retailers, an interesting option would be to modulate the physical space in such a way they can move part of the business to the online channel while maintaining certain stores as a showroom and point of delivery and return (Reynolds and Cuthbertson, 2004). Internet is also an important opportunity for new entrepreneurs, at least to start projects because they do not require a physical location to do it (IBM, 2012).

Another important aspect to consider is what is going to happen with discount or 'low cost' retailers. For some companies the recession is an opportunity to strength their businesses (Srinivasan et al., 2005) and the value clothing market has been, beyond doubt, one of the main beneficiaries of the economic crisis. Nevertheless, the shopping experience is still its main weakness. People buy in them, even if it is not their favourite store to do it or do no enjoy the experience, which generates a limited consumer loyalty (Mintel, 2009, Euromonitor International, 2009). Primark is the best example of this. They are increasing their product portfolio and improving the stores but since their main proposition is price, their intention to change the brand positioning can turn against its image (Mintel, 2010). Certain aspects can help to improve their image and a good example is George at Asda, a British retailer that is offering a 100-day warranty on garments which provide greater value to the consumer by ensuring that garments will last at least one season (Mintel, 2010).

In any case, in providing greater value, retailers must know what motivates consumers to buy on every channel. In this regard, the results indicate that both unemployed and workers buy in physical stores to escape themselves and when there is a sale. The first motivation is consistent with the theory of Nicholson's et al (2002), previously exposed, related to the role of the physical store to reinforce customers' mood, especially in the current times. Consumption can create little aesthetic pleasures even when the resources are small (Lehtonen, 1999). The 'cost-saving' motivation is also logical but it is curious that unemployed people do no consider the Internet for this objective. Workers do, using the channel primarily for convenience, cost-saving and variety seeking. It seems that workers are strongly motivated to use e-commerce while unemployed are still stuck in the physical store.

These findings lead us to emphasise the recommendations set out above. On the one hand, retailers must enhance the hedonic aspects of the shopping experience in their physical channels, so that consumers will evade and enjoy the experience and, on the other hand, they must boost the online channel and communicate its benefits to the consumer. Unemployed people share with low-income consumers the need to get the maximum value for their money and the Internet is key at this point. Not to be forgotten is the importance of generating a hedonic shopping experience also in this channel.

It is important for retailers to make the most of new market opportunities especially if these opportunities are supposed to grow in the long term as it is the case for digital shopping including e-commerce and m-commerce (Shama,1993). The success will be for retailers who are able to evaluate the role that every channel plays in consumers' needs and expectations. 


\section{Financiación del proyecto}

Marta Blázquez Cano es beneficiaria de una beca de posgrado otorgada por la Fundación Caja Madrid para desarrollar estudios de Doctorado en el Reino Unido. Este artículo forma parte de una investigación doctoral más amplia en la que se establece una comparativa entre las experiencias de compra de los consumidores de ambos países, dentro del sector textil. La investigación se ha desarrollado en el Oxford Institute of Retail Management (OXIRM) / Universidad de Oxford.

\section{Agradecimientos}

De forma muy especial al Dr. Jonathan Reynolds, por su asesoramiento y apoyo a lo largo de todo el proceso de investigación. El Dr. Jonathan Reynolds es director académico del OXIRM y mi supervisor durante mi tiempo de trabajo en la Universidad de Oxford.

\section{References}

Allard, T., Babin, B. and Chebat, J.C. (2009). "When income matters: customers evaluation of shopping mall's hedonic and utilitarian orientations". Journal of Retailing and Consumer Services, Vol.16, pp. 40-49.

Arnold, M. and Reynolds, K. (2003). "Hedonic shopping motivations". Journal of Retailing, Vol.79, pp. 77-95.

Babin, B., Darden, W. and Griffin, M. (1994). "Work and/or Fun: measuring hedonic and utilitarian shopping value". Journal of Consumer Research, Vol.20, pp. 644-656.

Bäckström, K. and Johansson, U. (2006). "Creating and consuming experiences in retail store environments: Comparing retailer and consumer perspectives”. Journal of Retailing and Consumer Services, Vol.13, Issue 6, pp. 417-430.

Ballantine, P. W., Jack, R. and Parsons, A. G. (2010). Atmospheric cues and their effect on the hedonic retail experience. International Journal of Retail and Distribution Management, 38(8), 641-653.

Barómetro de Empresas de Moda en España (2012). Report compiled by Modaes.es and Vente-privee.com, September, 2012.

Batra, R. and Ahtola, O. (1990). "Measuring the hedonic and utilitarian sources of consumer attitudes”. Marketing Letters, Vol. 2, Issue 2, pp. 159-170.

Bellenger, D. N. and Korgaonkar, P. K. (1980). "Profiling the recreational shopper". Journal of Retailing, Vol.56, Issue 3, pp. 77-92.

Bellenger, D. N., Robertson, D. H. and Hirschman, E. C. (1976). “Age and education as key correlates of store selection for female shoppers". Journal of Retailing, Vol.52, Issue 4, pp. 71-78. 
Bellenger, D. N., Robertson, D. H. and Greenberg B.A. (1977). "Shopping center patronage motives”. Journal of Retailing, Vol. 53, Issue 2, pp. 29.

Bernal, J.J., Martínez, S. and Sánchez J.F. (2004). “Modelización de los factores mas importantes que caracterizan un sitio en la red". XII Jornadas de ASEPUMA. September, 2004.

Biernacki, P. and Waldorf, D. (1981). "Snowball Sampling: Problems and techniques of chain referral sampling”. Sociological Methods and Research, Vol.10, pp. 141-163.

Camus and Bracewell, 2009. "Spanish online retail and travel forecast, 2008 to 2014”. Forrester Research, March, 2009.

Chandon, P., Wansink, B. and Laurent, G. (2000). "A benefit congruency framework of sales promotion effectiveness". Journal of Marketing, Vol. 64, Issue 4, pp. 65-81.

Childers, T. (2001). "Hedonic and utilitarian motivations for on line retail shopping behaviour". Journal of Retailing, Vol.77, Issue 4, pp. 511-535.

Chu, A. and Lam, M.C. (2007). "Store environment of fashion retailers: a Hong Kong perspective". In Hines, T. and Bruce, M., Fashion Marketing, 2 ${ }^{\mathrm{a}}$ Ed, Elsevier, pp. 151-167.

Clifford, E. (2012). "Fashion on line UK”. Mintel, March 2012.

Coleman, R. (1983). "The continuing significance of social class to marketing." Journal of Consumer Research, Vol.10, Issue 3.

Crowley, A., Spangenberg, E. and Hughes, K. (1992). "Measuring the hedonic and utilitarian dimensions of attitudes toward product categories" Market Letters, Vol. 3, Issue 3, pp. 239-249.

Dawson, S., Bloch, P.H. and Ridgway, N.M. (1990). "Shopping motives, emotional states and retail outcomes". Journal of Retailing, 66 (4), 408.

Dawson, J., and Larke, R. (2004). "Japanese retailing through the 1990s: retailer performance in a decade of slow growth". British Journal of Management, Vol. 15, Issue 1, pp. 73-94.

Eroglu, S., Machleit, K. and Davis, L. (2003). "Empirical testing of a model of online store atmospherics and shoppers responses”. Psychology and Marketing, Vol. 20, Issue 2 (February), pp. 139-150.

Euromonitor International (2009): “Global retailing. New concepts in retailing: the thin line between success and failure”. Euromonitor International, July 2009.

Euromonitor International (2011). "Internet retailing blazing growth path". Euromonitor International, June, 2011.

European Commission (2012). "Commission communication to the European Parliament, the Council, the Economic and Social Committe and the Committee of the Regions". A coherent framework for building trust in the digital single market for e-commerce and on line services”. European Commission, January, 2012.

Field, A. (2010). Discovering statistics using SPSS. $3^{\mathrm{a}}$ Ed., SAGE.

Ford, K., MacCallum, R. and Tait, M. (1986). "The application of exploratory factor analysis in applied psychology: a critical review and analysis" Personnel Psychology, Vol. 39. 
Henson, R. and Roberts, J. (2006). "Use of exploratory factor analysis in published research: common errors and some comment on improved practice". Educational and Psychological Measurement, Vol. 66, Issue 3, pp. 393-416.

Fundación Orange (2012). "eEspaña 2012. Informe anual sobre el desarrollo de la Sociedad de la Información en España”. Fundación Orange, 2012.

Gavilán Bouzas, D., Blasco López, F. and Avello Iturriagagoitia, M., 2010, "Shopping, hedonism and timestyle”, Esic Market Economics and Business Journal, Vol. 136, pp. 27-48.

Goldman, A. (1976). "Do lower-income consumers have a more restricted shopping scope?. Journal of Marketing, Vol. 40, Issue 1.

Grewal, D., Levy, M. and Kumar, V. (2009). "Customer experience management in retailing: an organizing framework". Journal of Retailing, Vol. 85, Issue 1, pp. 1-14.

Goodman, L. A. (1961). Snowball sampling. The Annals of Mathematical Statistics, pp. 148-170.

Hirschman, E. and Holbrook, M. (1982). "Hedonic consumption: emerging concepts, methods and propositions". Journal of Marketing, Vol. 46, Summer Issue, pp. 92-101.

IBM (2012). "Retail 2020. Reinventing retailing once again”. IBM - New York University Stern School of Business, January 2012.

INE (2012). "Encuesta de estructura salarial 2010". Nota de prensa. 26 ${ }^{\text {th }}$ June, 2012 (updated 27th September, 2012). www.ine.es.

INE (Dec. 2012). "Encuesta de población activa. EPA. Tasa de paro". www.ine.es

Initiative (2011). "The Reset Generation". Initiative Insight and innovation, 2011.

Irani, N. and Heidorzaden, K. (2011). "The effects of Iranian consumers' buying tendencies on hedonic and utilitarian shopping value". African Journal of Business Management, Vol. 5, Issue 17, pp. 7449-7460.

Jones, M., Reynolds, K. and Arnolds, M. (2006). "Hedonic and utilitarian shopping value: investigating differential effects on retail outcomes". Journal of Business Research, Vol.59, Issue 9, pp. 974-981.

Kaplan, C. D., Korf, D. and Sterk, C. (1987). "Temporal and social contexts of heroin-using populations: an illustration of the snowball sampling technique" Journal of Mental and Nervous Disorders, Vol. 175, Issue 9, pp. 566-574.

Kotler, P. (1973). "The major tasks of marketing management". Journal of Marketing, Vol. 37, October Issue, pp. 42-49.

Lehtonen, T. K. (1999). "Any room for aesthetics?: shopping practices of heavily indebted consumers". Journal of Material Culture, Vol. 4, Issue 3, pp. 243-262.

Levy, S. (1959). "Symbols for sale”. Harvard Business Review, Vol.37, July-August Issue.

Manning, H. and Dorsey, M. (2008). "Customer experience in a down economy". Forrester Research, December 2008.

Marciniak, R. and Bruce, M. (2007). "Fashion E-tailing". In Hines, T. and Bruce, M., Fashion Marketing, $2^{\text {a }}$ Ed., Elsevier, pp. 259-276. 
Martineau, P. (1958). "Social classes and spending behaviour". Journal of Marketing, Vol.23, pp. 121-130.

Millward Brown (2012). "Perspectivas del consumo. Índice del comportamiento del consumidor". Millward Brown, October 2012.

Mintel (2009). "Fashion store environments: UK”. Mintel, June 2009.

Mintel (2010). "Fashion: impact of the recession". Mintel Oxygen, June 2010.

Mintel (2010b): “E-commerce Europe: Spain”. Mintel, February 2010.

Mintel (2011). "Clothing Retailing: Spain”. Mintel, October 2011.

Nicholson, M., Clarke, J. and Blakemore, M. (2002). "One brand, three ways to shop: situational variables and multichannel consumer behaviour". Review of Retail, Distribution and Consumer Research, Vol.12, Issue 2, pp. 131-148.

Nielsen (2012). "Confianza del consumidor mundial". Nielsen Global Consumer Confidence Survey, 3rd term 2012.

ONTSI (2012): “Comercio electrónico B2C 2011. Edición 2012”. Observatorio Nacional de las Telecomunicaciones y de la Sociedad de la Información (ONTSI), October, 2012.

Oxford Futures Conference (Dec. 2012). Saïd Business School. University of Oxford. 10-11 December, 2012.

Passport (2012). "Consumer buying behaviour in the recession: global online survey”. Euromonitor International, January 2012.

Puccinelli, N., Goodstein, R., Grewal, D., Price, R., Raghubir, P. and Stewart, D. (2009). "Customer experience management in retailing: understanding the buying process". Journal of Retailing, Vol.85, Issue 1, pp. 15-30.

Pollok, M. and Schlitz, M. A. (1988): "Does voluntary testing matter? How it influences homosexual safer sex". Proceedings of 4th International Aids Conference. Stockholm, Sweden, June 1998.

PWC (2011). "Pick'n'Mix": Meeting the demands of the new multichannel shopper". Pricewaterhouse Coopers, April 2011.

Reynolds, J., and Cuthbertson, C. (2004). Retail Strategy: the view from the bridge. Elsevier, 2004.

Sands, S., and Ferraro, C. (2010). "Retailers' strategic responses to economic downturn: insights from down under". International Journal of Retail and Distribution Management, Vol. 38, Issue 8, pp. 567-577.

Shama, A. (1993). "Marketing strategies Turing recession: a comparison of small and large firms". Journal of Small Business Management, July Issue.

Seybert, H. (2011). "Internet use in households and by individuals in 2011". Eurostat, statistics in focus. 66/2011.

Shim, S. and Mahoney, M. Y. (1992). The elderly mail-order catalog user of fashion products. A profile of the heavy purchaser. Journal of Direct Marketing, Vol.6, Issue 1, pp. 49-58.

Siddiqui, N., O’Malley, A., McColl, J.C. and Birtwistle, G. (2003). "Retailer and consumer perceptions of online fashion retailers: Web site design issues". Journal of Fashion Marketing and Management, Vol.7, Issue 4, pp. 345-355. 
Sit, J., Merrilees, B. and Birch, D. (2003). "Entertainment-seeking shopping centre patrons: the missing segments”. International Journal of Retail and Distribution Management, Vol.31, Issue 2/3, pp. 80.

Srinivasan, R., Rangaswamy, A. and Lilien, G.L. (2005). "Turning adversity into advantage: does proactive marketing during a recession pay off?". International Journal of Research in Marketing, Vol.22, Issue 2, pp. 109-125.

Stephenson, P.R. and Willett, R.P. (1969). "Analysis of consumers' retail patronage strategies". Marketing Involvement in Society and the Economy, pp. 316-322.

Stone, G.P (1954). "City and urban identification: observations on the social psychology of city life”. American Journal of Sociology, Vol.60, July Issue, pp. 36-45.

Surchi, M. (2011). "The temporary store: a new marketing tool for fashion brands". Journal of Fashion Marketing and Management, Vol.15, Issue 2, pp. 257-270.

Tauber, E. M. (1972). "Why do people shop?”. Journal of Marketing, Vol.36, Issue 4.

To, P.L., Chechen, L. and Lin, T.H (2007). "Shopping motivations on Internet: a study based on utilitarian and hedonic value”. Technovation, Vol.27, pp. 774-787.

Van Meter, K. (1990). “Methodological and Design Issues: Techniques for Assessing the Representatives of Snowball Samples" NIDA (National Institute on Drug Abuse). Research Monograph, pp. 31-43.

Verhoef, P., Lemon, K., Parasuraman, A., Roggeveen, A., Tsiros, M. and Schlesinger, L. (2009). "Customer experience creation: determinants, dynamics and management strategies". Journal of Retailing, Vol.85, Issue 1, pp. 31-41.

Watchravesringkan, K. and Shim, S. (2003). "Information search and shopping intentions through Internet for apparel products". Clothing and Textiles Research Journal, Vol.21, Issue 1, pp. 1-7.

Westbrock, R.A. and Black, W.C. (1985). “A motivation-based shopper typology”. Journal of Retailing, Vol.61, Spring Issue, pp. 78-103.

Westbrook. G. (2012). “10 Global Consumer Trends for the next 5 years. Strategy briefing”. Passport, Euromonitor International, November 2012.

Eastlick, M. A. and Feinberg, R. A. (1999). "Shopping motives for mail catalog shopping”. Journal of Business Research, Vol.45, Issue 3, pp. 281-290.

Zeithaml, V. (1988). "Consumer perceptions of price, quality and value: a meansend model and synthesis of evidence". Journal of Marketing, Vol.52, pp. 2-22.

Zhang, J., Farris, P., Irvin, J., Kushwaha, T., Steenburgh, T. and Weitz, B. (2010). "Crafting integrated multichannel retail strategies". Journal of Interactive Marketing, Vol.24, pp. 168-180. 


\section{Notes on Contributors}

Name: Marta Blázquez Cano

Position: Research Associate

School / Faculty: School of Materials/ Design \& Fashion Business Research Group

University: University of Manchester

Address: Sackville Street Building, Manchester M13 9PL

Telephone: (44)(0)7412305381

Email: marta.blcano@gmail.com

Name: María Puelles Gallo

Position: Profesor Contratado, Doctor

School / Faculty: Departamento de Investigación y Comercialización de Mercados

University: Universidad Complutense de Madrid

Address: Campus de Somosaguas s/n. Edif. 6. desp. 35. Madrid 28224

Telephone: 91 3942438/2469

Email:mpuelles@ccee.ucm.es 